\title{
КІЛЬКІСНА МОРФОЛОГІЧНА ОЦІНКА ОСОБЛИВОСТЕЙ РЕМОДЕЛЮВАННЯ М'ЯЗОВОї ОБОЛОНКИ ПОРОЖНЬОЇ КИШКИ ПРИ ВИДАЛЕННІ РІЗНИХ ОБ'ЄМІВ ПАРЕНХІМИ ПЕЧІНКИ
}

\section{๑А. Г. Шульгай, Л. В. Татарчук, М. С. Гнатюк ДВНЗ «Тернопільський державний медичний університет імені І. Я. Горбачевського МОз України»}

РЕзЮМЕ. Видалення великих об'ємів паренхіми печінки може супроводжуватися виникненням пострезекційної портальної гіпертензії. Остання призводить до морфологічної перебудови органів басейну ворітної печінкової вени, ураження їх структур, морфологічних змін м'язової оболонки, які при ушкоженнях порожньої кишки у названих патологічних умовах досліджені недостатньо.

Мета - морфометричними методами вивчити особливості ремоделювання м'язової оболонки порожньої кишки при видаленні різних об'ємів паренхіми печінки.

Матеріал і методи. Комплексом морфологічних методів досліджена порожня кишка 45 статевозрілих білих щурів-самців, які були поділені на 3-и групи. 1-а група нараховувала 15 інтактних тварин, 2-а - 15 щурів, у яких було видалено 31,5 \% паренхіми печінки, 3-я - 15 тварин після резекції 58,1 \% паренхіми печінки. Евтаназія щурів здійснювалася кровопусканням в умовах тіопенталового наркозу через 1 місяць від початку експерименту. Із порожньої кишки виготовляли гістологічні мікропрепарати. Вимірювали товщини колового та поздовжнього шарів м'язової оболонки, діаметри гладких міоцитів та їх ядер, ядерно-цитоплазматичні відношення у цих клітинах, стромально-міоцитарні відношення, відносні об'єми пошкоджених міоцитів. Кількісні показники обробляли статистично.

Результати. Встановлено, що через місяць після резекції 31,5 \% паренхіми печінки досліджувані морфометричні показники змінювалися незначно. Видалення 58,1 \% паренхіми печінки призводило до розвитку пострезекційної портальної гіпертензії. Виражено зміненими при цьому виявилися морфометричні параметри структур колового та поздовжнього шарів м'язової оболонки порожньої кишки. Товщина колового шару м'язової оболонки через місяць після резекції 58,1 \% паренхіми печінки статистично достовірно ( $<<0,05)$ зменшилася на 4,1 \%, діаметр міоцитів - на 6,1 \%, ядерно-цитоплазматичні відношення у них зросли на 35,4 \%, стромально-міоцитарні відношення - на 14,3 \%, відносний об'єм пошкоджених міоцитів - у 14,4 рази. Кількісні морфологічні показники структур поздовжнього шару м'язової оболонки порожньої кишки через місяць після резекції 58,1 \% паренхіми печінки змінювалися аналогічно, але ступінь їх вираження був меншим, порівняно із структурами колового шару. Так, діаметр міоцитів у даних експериментальних умовах виявився зменшеним всього на 1,6 \%, діаметр ядер зріс на 4,6\% (p<0,01), ядерно-цитоплазматичні відношення - на 15,2 \% ( $<<0,001)$, стромально-міоцитарні відношення на 14,1\%, відносний об'єм пошкоджених міоцитів - у 8,1 раза.

Висновки. Видалення великих об'ємів паренхіми печінки призводить до пострезеційної портальної гіпертензії та вираженого ремоделювання структур колового та поздовжнього шарів м'язової оболонки порожньої кишки, яке характеризується диспропорційними нерівномірними змінами морфометричних параметрів гладких міоцитів, їх ядер, порушеннями ядерно-цитоплазматичних відношень у цих клітинах, атрофією, зростанням стромальних структур та відносних об'ємів пошкоджених міоцитів у м'язовій оболонці, що може ускладнюватися дисфункцією ушкодженого органа.

КлючОВІ СлОВА: резекція печінки; порожня кишка; м'язова оболонка; ремоделювання.

Вступ. Сьогодні у хірургічних клініках нерідко виконують резекцію печінки, яка здійснюється при доброякісних і злоякісних пухлинах, метастазах, травмах печінки, внутрішньопечінковому холангіолітіазі, альвеолярному ехінококозі, трансплантації печінки $[2,3,13]$. Резекція великих об'ємів печінки може призводити до різних ускладнень, в тому числі й до портальної пострезекційної гіпертензії, при якій підвищується тиск у системі ворітної печінкової вени, печінкових венах, а також у нижній порожнистій вені $[2,10,12]$. Головними клінічними ознаками портальної гіпертензії $є$ розширення і повнокров'я ворітної печінкової вени, брижових вен, варикозне розширення вен стравоходу і шлунка, гемороїдальних вен, вен передньої черевної стінки, шлунково- кишкові кровотечі, спленомегалія, асцит. Порожня кишка належить до органів, венозний дренаж від яких здійснюється через ворітну печінкову вену, де гемодинамічні розлади ускладнюються різними морфологічними змінами у судинах та структурах досліджуваного органа. Необхідно вказати, що особливості ремоделювання структур м'язової оболонки порожньої кишки при пострезекційній портальній гіпертензії вивчені недостатньо [3].

Мета - морфометричними методами вивчити особливості ремоделювання м'язової оболонки порожньої кишки при видаленні різних об'ємів паренхіми печінки.

Матеріал і методи дослідження. Дослідження проведені на 45 лабораторних білих ста- 
Огляди літератури, оригінальні дослідження, погляд на проблему, ювілеї

тевозрілих щурах-самцях, які були поділені на 3-и групи. 1-а група включала 15 інтактних тварин (контрольна), 2-а - 15 щурів після резекції лівої бокової частки - 31,5 \% паренхіми печінки, 3-я 15 тварин після видалення правої і лівої бокових часток печінки (58,1 \%) [3]. Евтаназію тварин здійснювали кровопусканням в умовах тіопентал-натрієвого наркозу через 1 місяць від початку експерименту. Усі маніпуляції та евтаназію щурів проводили з дотриманням основних принципів роботи з експериментальними тваринами відповідно до положення «Європейської конвенції про захист хребетних тварин, які використовуються для експериментальних та інших наукових цілей» (Страсбург, 1986 р.), «Загальних етичних принципів експериментів на тваринах», ухвалених Першим національним конгресом з біоетики (Київ, 2001 р.), а також Закону України "Про захист тварин від жорстокого поводження" (від 21.02.2006р.) [4], наказу МОНМС України № 249 від 01.03.2012р. «Порядок проведення науковими установами дослідів, експериментів на тваринах».

Вирізані шматочки із порожньої кишки фіксували в 10 \% нейтральному розчині формаліну i після відповідного проведення через етилові спирти зростаючої концентрації заливали у парафінові блоки за загальноприйнятою методикою. Мікротомні зрізи товщиною 5-7 мкм після депарафінізації фарбували гематоксиліном-еозином, за ван-Гізон, Маллорі, Вейгертом, толуїдиновим синім [9]. Морфометрично на мікропрепаратах вимірювали товщини колового (ТКШ) та поздовжнього (ТПШ) шарів м'язової оболонки, діаметри гладких міоцитів вказаних шарів (ДМК, ДМП), діаметри їх ядер (ДяК, ДяП), визначали ядерно-цитоплазматичні відношення у (ЯЦВК, ЯЦВП) у досліджуваних клітинах, стромально-міоцитарні від- ношення у названих шарах м'язової оболонки (СМВК, СМВП), відносні об'єми пошкоджених міоцитів у них (ВОПМК, ВОПМП $[1,3]$. Морфометрію вказаних структур проводили за допомогою світлового мікроскопа "Olimpus BX-2" з цифровою відеокамерою і пакетом прикладних програм "Відео Тест 5,0" та "Відео розмір 5,0". Кількісні величини оброблялися статистично. Обробка результатів виконана у відділі системних статистичних досліджень ДВНЗ «Тернопільський державний медичний університет імені І. Я. Горбачевського MO3 України» в програмному пакеті Statsoft STATISTIKA. Різницю між порівнюваними величинами визначали за критеріями Манна-Уїтні та Стьюдента [5].

Результати й обговорення. Отримані морфометричні параметри структур м'язової оболонки порожньої кишки дослідних тварин представлені в таблиці 1. Усестороннім аналізом наведених у вказаній таблиці даних встановлено, що товщина колового шару м'язової оболонки непошкодженої порожньої кишки з вираженою статистичною достовірністю $(p<0,001)$ у 1,4 раза перевищувала аналогічний морфометричний показник поздовжнього шару. Неодинаковими при цьому виявилися діаметри гладких міоцитів та їх ядер у досліджуваних шарах м'язової оболонки порожньої кишки. Більші вказані кількісні морфологічні показники колового шару м'язової оболонки, порівняно з поздовжнім, свідчать, що попередня структура інтенсивніше функціонує та виконує більшу роботу і $\epsilon$ більш потужною. Ядерно-цитоплазматичні відношення у гладких міоцитах, стромально-міоцитарні відношення, відносні об'єми пошкоджених міоцитів у досліджуваних шарах м'язової оболонки неушкодженої порожньої кишки підтверджували наведене вище [3].

Таблиця 1. Морфометрична характеристика м'язової оболонки порожньої кишки експериментальних тварин $(\mathrm{M} \pm \mathrm{m})$

\begin{tabular}{|l|c|c|c|}
\hline \multirow{2}{*}{ Показник } & \multicolumn{2}{|c|}{ Група спостереження } \\
\cline { 2 - 4 } & 1 -а & 2 -а & 3 -я \\
\hline ТКШ, МКм & $56,65 \pm 0,45$ & $56,40 \pm 0,48$ & $54,30 \pm 0,42^{*}$ \\
\hline ДМК, МКм & $9,05 \pm 0,06$ & $9,10 \pm 0,05$ & $3,50 \pm 0,03^{* * *}$ \\
\hline ДЯК, МКм & $2,80 \pm 0,02$ & $2,85 \pm 0,03$ & $0,130 \pm 0,003^{* * *}$ \\
\hline ЯЦВК & $0,096 \pm 0,001$ & $0,098 \pm 0,001$ & $0,144 \pm 0,002^{* * *}$ \\
\hline СМВК & $0,126 \pm 0,002$ & $0,130 \pm 0,003$ & $32,60 \pm 0,36^{* * *}$ \\
\hline ВОПМК, \% & $2,26 \pm 0,02$ & $4,30 \pm 0,04^{* * *}$ & $33,80 \pm 0,36^{* * *}$ \\
\hline ТПШ, МКМ & $39,80 \pm 0,33$ & $39,50 \pm 0,42$ & $6,02 \pm 0,03^{*}$ \\
\hline ДМП, МКМ & $6,12 \pm 0,04$ & $6,14 \pm 0,03$ & $2,96 \pm 0,02^{* *}$ \\
\hline ДЯП, МКМ & $2,83 \pm 0,02$ & $2,83 \pm 0,02$ & $0,242 \pm 0,003^{* * *}$ \\
\hline ЯЦВП & $0,210 \pm 0,002$ & $0,212 \pm 0,003$ & $0,146 \pm 0,002^{* * *}$ \\
\hline СМВП & $0,128 \pm 0,001$ & $0,130 \pm 0,002$ & $17,30 \pm 0,12^{* * *}$ \\
\hline ВОПМП, \% & $2,14 \pm 0,02$ & $3,50 \pm 0,03^{* * *}$ & \\
\hline
\end{tabular}

Примітка. * - p<0,05; ** - p<0,01; *** - p<0,001, порівняно з 1-ю групою спостережень. 
Огляди літератури, оригінальні дослідження, погляд на проблему, ювілеї

Через місяць після резекції 31,5 \% паренхіми печінки наведені морфометричні параметри колового та поздовжнього шарів м'язової оболонки порожньої кишки змінювалися незначно. У досліджуваних експериментальних умовах виявлено статистично достовірне ( $p<0,001)$ збільшення відносного об'єму пошкоджених міоцитів у коловому шарі у 1,9 раза, а у поздовжньому у 1,6 раза. Серед пошкоджених міоцитів спостерігалися переважно апоптично змінені клітини, що може бути обумовлено зростанням їх кількості при стресових ситуаціях (оперативні втручання) та віком $[6,11]$.

У дослідних тварин через місяць після резекції 58,1 \% паренхіми печінки при розтині очеревинної порожнини спостерігалося розширення печінкової ворітної вени, повнокров'я і розширення брижових вен та видимого венозного русла тонкої та товстої кишок, асцит, спленомегалія. Слизова оболонка порожньої кишки повнокровна, набрякла, з поодинокими осередками точкових крововиливів. Описане вище свідчило про наявність пострезекційної портальної гіпертензії $[3,13]$.

У даних експериментальних умовах виявлено виражене ремоделювання структур м'язової оболонки порожньої кишки, що підтверджувалося змінами її морфометричних параметрів. Так, товщина колового шару досліджуваного органа зменшилася $з(56,65 \pm 0,45)$ мкм до $(54,30 \pm 0,42)$ мкм. Наведені кількісні морфологічні показники статистично достовірно $(p<0,05)$ відрізнялися між собою і останній морфометричний параметр виявився меншим за попередній на 4,1\%. Діаметр гладких міоцитів даного шару м'язової оболонки порожньої кишки у досліджуваних експериментальних умовах з вираженою статистично достовірною різницею (р<0,001) зменшився на 6,1%. Діаметр ядер вказаних клітин збільшився на 9,3\% ( $<<0,001)$. Нерівномірні, диспропорційні зміни просторових характеристик гладких міоцитів та їх ядер у коловому шарі м'язової оболонки порожньої кишки через місяць після видалення 51,8 \% паренхіми печінки призводили до порушень ядерно-цитоплазматичних відношень у названих клітинах. Вказаний морфометричний параметр при цьому виявився статистично достовірно ( $<<0,001)$ збільшеним на 35,4 \%. Виражено зростали у даних експериментальних умовах стромально-міоцитарні відношення та відносний об'єм пошкоджених міоцитів у даному шарі м'язової оболонки порожньої кишки. Вказані морфометричні параметри при цьому відповідно збільшилися на $14,3 \%(p<0,001)$ та у 14,4 раза $(p<0,001)$. Варто вказати, що деякі дослідники виражені зміни співвідношень між ядром та цитоплазмою клітин вважають порушенням клітинного, а анало- гічні зміни між міоцитами та стромою - тканинного структурного гомеостазів $[3,7,8]$.

Кількісні морфологічні показники структур поздовжнього шару м'язової оболонки порожньої кишки через місяць після резекції 58,1 \% паренхіми печінки змінювалися аналогічно, але ступінь їх вираження був дещо меншим, порівняно із структурами колового шару. Так, діаметр міоцитів у даних експериментальних умовах виявився зменшеним всього на 1,6 \%, діаметр ядер зріс на $4,6 \%$ ( $<<0,01)$, ядерно-цитоплазматичні відношення - на 15,2 \% (р<0,001), стромально-міоцитарні відношення - на 14,1 \%, відносний об'єм пошкоджених міоцитів - у 8,1 раза.

Світлооптично в оболонках стінки порожньої кишки спостерігалися виражені судинні розлади, набряки строми, осередки дистрофічно, некробіотично, апоптично змінених епітеліоцитів, гладких міоцитів, вогнищеві інфільтрати та розростання сполучної тканини. Відмічався також набряк ендотеліоцитів, їх дистрофія, некробіоз, десквамація та проліферація. Останнє свідчило про наявність гіпоксії. Виражене пошкодження більшості ендотеліоцитів може призводити до ендотеліальної дисфункції та посилювати ушкодження клітин та тканин [6]. Варто також зазначити, що виявлені патогістологічні ушкодження стінки порожньої кишки в умовах пострезекційної портальної гіпертензії корелювали з такими морфометричними параметрами, як ядерно-цитоплазматичні відношення у гладких міоцитах, стромально-міоцитарні відношення у м'язовій оболонці органа, відносний об'єм ушкоджених міоцитів. Відомо, що наявне венозне повнокров'я призводить до тканинної гіпоксії, яка сприяє депривації компенсаторних механізмів адаптації та зниженню резистентності клітинних структур до пошкоджувальної дії негативних чинників метаболізму $[7,11]$. Морфометричні виміри структур порожньої кишки та отримані результати свідчать, що в умовах пострезекційної портальної гіпертензії у названому органі виникають атрофічні процеси (зменшення розмірів структур, заміна клітин сполучною тканиною), що обумовлено гіпоксією, запальними процесами та імунними реакціями, що мають місце при змодельований патології $[7,11]$. Виявлені зміни у м'язовій оболонці можуть призводити до порушення моторики та дисфункції кишки $[3,12]$.

На основі отриманих результатів проведеного дослідження та даних літератури можна стверджувати, що видалення великих об'ємів паренхіми печінки призводить до пострезекційної портальної гіпертензії та вираженої структурної перебудови (ремоделювання) колового і поздовжнього шарів м'язової оболонки порожньої кишки, що 
Огляди літератури, оригінальні дослідження, погляд на проблему, ювілеї

характеризується нерівномірними диспропорційними змінами просторових характеристик структур органа, порушенням відношень між ними, судинними розладами, набряком, дистрофічними, некробіотичними змінами епітеліоцитів, міоцитів, ендотеліоцитів, стромальних елементів, атрофічними, інфільтративними та склеротичними процесами.

Висновки. Видалення значних об'ємів паренхіми печінки призводить до пострезекційної портальної гіпертензії та вираженого ремоделювання структур колового і поздовжнього шарів м'язової оболонки порожньої кишки, яке характеризується диспропорційними нерівномірними змінами морфометричних параметрів гладких міоцитів, їх ядер, порушеннями ядерно-цитолазматичних відношень у цих клітинах, стромально-міоцитарних відношень, атрофією, зростанням стромальних структур та відносних об'ємів ушкоджених міоцитів у м'язовій оболонці, що може ускладнюватися дисфункцією органа.

Перспективи подальших досліджень. Всестороннє адекватне кількісне морфологічне вивчення закономірностей ремоделювання структур м'язової оболонки порожньої кишки в умовах пострезекційної портальної гіпертензії дозволить суттєво розширити діагностику, корекцію та профілактику досліджуваної патології.

\section{ЛІТЕРАТУРА}

1. Автандилов Г. Г. Основы количественной патологической анатомии / Г. Г. Автандилов. - М. : Медицина, 2002. -240 c.

2. Вишневський В. А. Сегментарне резекции, отдаленные результаты при злокачественных опухолях печени / В. А. Вишневский, М. Г. Ефанов, И. В. Казаков // Укр. журнал хірургії. - 2012. - № 1 (16). - С. 5-15.

3. Гнатюк М. С. Морфометрична оцінка особливостей ремоделювання структур дванадцятипалої кишки при резекції різних об'ємів печінки / М. С. Гнатюк, Л. В. Татарчук, О. Б. Ясіновський // Науковий вісник Ужгородського університету. Серія «Медицина». - 2016. Вип. 1 (53). - С. 92-95.

4. Загальні етичні принципи експериментів на тваринах // Ендокринологія. - 2003. - Т. 8, № 1. - С. 142-145.

5. Лапач С. Н. Статистические методы в медикобиологических исследованиях Excell / С. Н. Лапач, А. В. Губенко, П. Н. Бабич. - К. : Морион, 2001. - 410 с.

6. Макаров М. А. Роль дисфункции эндотелия и ригидности артерий в патогенезе хронической обструктивной болезни легких / М. А. Макаров, С. Н. Авдеев, А. Г. Чучалин // Терапевтический архив. - 2012. - № 3. - С. 74-80.

7. Мосийчук Л. Н. Хронический гастрит / Л. Н. Мосийчук, М. Ю. Зак // Новости медицины и фармации. 2010. - № 21 (349). - C. 12-15.

\section{REFERENCES}

1. Avtadnilov, G.G. (2002). Osnovy kolichestvennoy patologicheskoy anatomii [Basis of quantitative pathological anatomy]. Moscow: Meditsyna [in Russian].

2. Vishnevskiy, V.A., Yefanov, M.G., \& Kazakov, I.V. (2012). Segmentarnyye rezektsyi, otdalennyye rezultaty pri zlokachestvennykh opukholyakh pechieni [Segmentar resections, long-term results in malignant liver tumors]. Ukr. Zhurnal Khirurhii - Ukrainian Journal of Surgery, 1 (16), 5-15 [in Russian].

3. Hnatiuk, M.S., Tatarchuk, L.V., \& Yasinovskyi, O.B. (2016). Morfometrychna otsinka osoblyvostei remodeliuvania struktur dvanadtsiatypaloi kyshky pry resektsii riznykh obiemiv pechinky [Morphometric evaluation of the
8. Саркисов Д. С. Структурные основы адаптации и компенсации нарушенных функций / Д. С. Саркисов. М. : Медицина, 1998. -230 с.

9. Сорочинников А. Г. Гистологическая и микроскопическая техника / А. Г. Сорочинников, А. Е. Доросевич. - М. : Медицина, 2007. - 448 с.

10. Федоров В.Д. Основные осложнения обширных резекций печени и пути их предупреждения / В. Д. Федоров, В. А. Вишневский, Н. А. Назаренко [и др.] // Бюлл. сибирской медицины. - 2007. - № 4. - С. 16-24.

11. Хухліна О. С. Бронхіальна астма та хронічний холецистит: особливості клітинного перебігу, механізми взаємообтяження, шляхи патогенної корекції / О. С. Хухліна, Т. В. Дудка, Г. І. Шумко. - Чернівці : БДМУ, 2018. -194 c.

12. Шульгай А. Г. Особливості ремоделювання судин гемомікроциркуляторного русла клубової кишки при резекціях різних об'ємів печінки / А. Г. Шульгай, Л. В. Татарчук, М. С. Гнатюк // Вісник наукових досліджень. - 2017. - № 4. - С. 148-149.

13. Nanashima A. A modified grading system for posthepatectomy metastatic liver

cancer originating form colorectal carcinoma / A. Nanashima, Y. Sumida, T. Abo // J. Surg. Oncol. - 2008. № 98. - P. 363-370.

features of remodeling of duodenal structures during resection of different volumes of the liver]. Naukovyi visnyk Uzhhorodskoho universytetu. Seriia "Medytsyna" Scientific Journal of Uzhhorod University. Series "Medicine", 1 (49), 3-5 [in Ukrainian].

4. (2003). Zahalni etychni pryntsypy eksperymentiv na tvarynakh [General ethical principles of experiments on animals]. Endokrynolohiia - Endocrinology, 8, 1, 142-145 [in Ukrainian].

5. Lapach, S.N., Gubenko, A.V. Babich, P.N. (2001). Statistichieskiye metody $v$ mediko-biologicheskikh issledovaniyakh Excell [Statistical methods in medicobiological investigations Excell]. Kyiv: Morion [in Ukrainian]. 
Огляди літератури, оригінальні дослідження, погляд на проблему, ювілеї

6. Makarov, M.A., Avdyeyev, S.G., Chuchalin, A.G. (2012). Rol disfunktsyi endoteliya i regidnosti arteriy v patogeneze khronicheskoy obstruktivnoy bolezni legkikh [Role of endothelial cell disfunction in medical and biological investigation]. Terapevticheskiy arkhiv - Theraputical Archive, 3, 74-80 [in Russian].

7. Mosiichuk, L.N., \& Zak, M.Yu. (2010). Khronichnyi hastryt [Chronic gastritis]. Novosti meditsyny i farmatsyi News of Medicine and Pharmacy, 21 (349), 12-15 [in Ukrainian].

8. Sarkisov, D.S. (1998). Strukturnyye osnovy adaptatsyi i kompensatsyi narushennykh funktsyy [Structural basis adaptation and compensation damage function]. Moscow: Meditsina [in Russian].

9. Sorochinnikov, A.G., \& Dorosevich, A.Ye. (2007). Gistologicheskaya i mikroskopicheskaya tekhnika [Histological and microscopic equipments]. Moscow: Meditsyna [in Russian].

10. Fedorov, V.D., Vishnevskiy, V.A., \& Nazarenko, N.A. (2007). Osnovnye oslozhneniya obshyrnykh rezektsyy pecheni i puti ikh preduprezhdeniya [The main complications

of extensive liver resections and ways to prevent them]. Byull. Sibirskoy meditsyny - Bulletin of Siberian Medicine, 4, 16-24 [in Russian].

11. Khukhlina, O.S., Dudka, T.V., \& Shumko, H.I. (2018). Bronkhialna astma ta khronichnyi kholetsystyt: osoblyvosti klitynnoho perebihu, mekhanizm vzaiemoobtiazhennia, shliakhy patohennoi korektsii [Bronchial asthma and chronic cholecystitis: features of the cellular flow, mechanisms of mutual burden, pathogenic correction]. Chernivtsi: BDMU [in Ukrainian].

12. Shulhai, A.H., Tatarchuk, L.V., \& Hnatiuk, M.S. (2017). Osoblyvosti remodeliuvania sudyn hemomikrotsyrkulatornoho rusla klubovoi kyshky pry resektsii riznykh obiemiv pechinky [Remodeling peculiarities of ileum hemomicrocirculatory bed vessels at resection of different liver size]. Visnyk naukovykh doslidzhen - Scientific Journal of Investigation, 4, 145-149 [in Ukrainian].

13. Nanashima, A., Sumida, Y., \& Abo, T. (2008). A modified grading system for post-hepatectomy metastatic liver cancer originating form colorectal carcinoma. J. Surg. Oncol., 98, 363-370.

\title{
КОЛИЧЕСТВЕННАЯ МОРФОЛОГИЧЕСКАЯ ОЦЕНКА ОСОБЕННОСТЕЙ РЕМОДЕЛИРОВАНИЯ МЫШЕЧНОЙ ОБОЛОЧКИ ТОЩЕЙ КИШКИ ПРИ УДАЛЕНИИ РАЗЛИЧНЫХ ОБЪЕМОВ ПАРЕНХИМЫ ПЕЧЕНИ
}

\author{
๑А. Г. Шульгай, Л. В. Татарчук, М. С. Гнатюк \\ ГВУз «Тернопольский государственный медицинский университет имени И. Я. Горбачевского \\ МОЗ Украины»»
}

РЕЗЮМЕ. Удаление больших объемов паренхимы печени может сопровождаться возникновением пострезекционной портальной гипертензии. Последняя приводит к морфологической перестройке органов бассейна воротной печеночной вены, поражению их структур, морфологическими изменениями мышечной оболочки, которые при повреждениях тощей кишки в названных патологических условиях исследованы недостаточно.

Цель - морфометрическими методами изучить особенности ремоделирования мышечной оболочки тощей кишки при удалении различных объемов паренхимы печени.

Материал и методы. Комплексом морфологических методов исследована тощая кишка 45 половозрелых белых крыс-самцов, которые были поделены на 3-и группы. Первая группа насчитывала 15 интактных животных, вторая - 15 крыс, у которых было удалено 31,5 \% паренхимы печени, третья - 15 животных после резекции 58,1 \% паренхимы печени. Эвтаназия крыс осуществлялась кровопусканием в условиях тиопенталового наркоза через 1 месяц после начала эксперимента. Из тощей кишки изготавливали гистологические микропрепараты. Измеряли толщины кругового и продольного слоев мышечной оболочки, диаметры гладких миоцитов и их ядер, ядерноцитоплазматические соотношения в этих клетках, стромально-миоцитарные соотношения, относительные объемы поврежденных миоцитов. Количественные показатели обрабатывались статистически.

Результаты. Установлено, что через месяц после резекции 31,5 \% паренхимы печени исследуемые морфометрические показатели менялись незначительно. Удаление 58,1 \% паренхимы печени приводило к развитию пострезекционной портальной гипертензии. Выражено измененными при этом оказались морфометрические параметры структур кругового и продольного слоев мышечной оболочки тощей кишки. Толщина кругового слоя мышечной оболочки через месяц после резекции 58,1 \% паренхимы печени статистически достоверно уменьшилась на 4,1 \%, диаметр миоцитов - на 6,1 \%, ядерно-цитоплазматические соотношения у них возросли на 35,4 \%, стромально-миоцитарные соотношения - на 14,3 \%, относительный объем поврежденных миоцитов - в 14,4 раза. Количественные морфологические показатели структур продольного слоя мышечной оболочки тощей кишки через месяц после резекции 58,1 \% паренхимы печени изменялись аналогично, но степень их выраженности была меньшей, по сравнению со структурами кругового слоя. Так, диаметр миоцитов в данных экспериментальных условиях оказался уменьшенным всего на 1,6 \%, диаметр ядер увеличился на 4,6 \% (р<0,01), ядерно-цитоплазматические соотношения - на 15,2% (р<0,001), стромально-миоцитарные соотношения - на 14,1 \%, относительный объем поврежденных миоцитов-в 8,1 раза. 
Выводы. Удаление больших объемов паренхимы печени приводит к пострезекционной портальной гипертензии и выраженному ремоделированию структур кругового и продольного слоев мышечной оболочки тощей кишки, которые характеризуются диспропорциональными неравномерными изменениями морфометрических параметров гладких миоцитов, их ядер, нарушениями ядерно-цитоплазматических соотношений в этих клетках, атрофией, увеличением стромальных структур и относительных объемов поврежденных миоцитов в мышечной оболочке, что может осложняться дисфункцией поврежденного органа.

КЛЮчЕВЫЕ СЛОВА: резекция печени; тощая кишка; мышечная оболочка; ремоделирование.

\title{
QUANTITATIVE MORPHOLOGICAL ASSESSMENT OF FEATURES OF REMODELING OF THE MUSCULAR LAYER OF JEJUNUM AT THE RESECTION OF DIFFERENT VOLUMES OF LIVER PARENCHYMA
}

\author{
@A. H. Shulgai, L. V. Tatarchuk, M. S. Hnatjuk \\ I. Horbachevsky Ternopil State Medical University
}

SUMMARY. Liver resection is widely used in modern surgical departments. Resections of large volumes of liver parenchyma are complicated by postresection portal hypertension, which leads to structural and functional changes in the organs of the basin portal hepatic vein. The features of the structural reconstruction of jejunum muscle at postresection portal hypertension have not been adequately investigated. The aim - using the morphometrical methods to study the features of remodeling of the structures of muscular layer of jejunum at resection of different volumes of liver parenchyma.

Materials and Methods. The complex of morphological methods examined the jejunum of 45 sexuale mature white male rats, which were divided into 3 groups. The group 1 consisted of 15 intact animals, group $2-15$ rats, in which $31.5 \%$ of the liver parenchyma was removed, group 3-15 animals after resection of $58.1 \%$ of liver parenchyma. Euthanasia of rats was carried out by bloodletting in conditions of thiopental anesthesia 1 month from the beginning of the experiment. Histological preparations were made from the jejunum. The thickness of the circular and longitudinal muscular layers, the diameters of smooth myocytes and their nuclei, the nuclear-cytoplasmic relations in these cells, the stromal-myocytal relations, and the relative volumes of damaged myocytes were measured. Quantitative indicators were processed statistically.

Results and Discussion. It was established that one month after resection of $31.5 \%$ of liver parenchyma, morphometric indices were slightly changed. Removal of $58.1 \%$ of liver parenchyma leads to the development of postresection portal hypertension. The morphometric parameters of the structures of the circular and longitudinal muscular layers of the jejunum were manifested by altered ones. The thickness of the circular muscular layer a month after the resection of $58.1 \%$ of the liver parenchyma statistically significantly decreased by $4.1 \%$, the diameter of myocytes - by $6.1 \%$, the nuclear-cytoplasmic relation of them increased by $35.4 \%$, stromally - myocytal relation - by $14.3 \%$, relative the number of damaged myocytes - by 14.4 times. Quantitative morphological indices of the structures of the longitudinal muscular layer of the jejunum a month after the resection of $58.1 \%$ of the liver parenchyma changed in a similar manner, but the degree of their expression was smaller compared with the structures of the circular muscular layer. Thus, the diameter of myocytes in the given experimental conditions was reduced by only $1.6 \%$, the diameter of the nuclei increased by $4.6 \%$ ( $p<0.01)$, nuclear-cytoplasmic relations - by $15.2 \%$ ( $p<0.001)$, stromally-miocytal relations - by $14.1 \%$, relative volume of damaged myocytes - by 8.1 times.

Conclusions. Removal of large volumes of liver parenchyma leads to postresection portal hypertension and pronounced remodeling of the structures of the circular and longitudinal muscular layers of the jejunum, characterized by disproportional uneven changes in the morphometric parameters of smooth myocytes, their nuclei, violations of nuclear-cytoplazmatic relations in these cells, atrophy, growth of stromal structures and relative volumes of damaged myocytes in the muscular layer, which may be complicated by the dysfunction of the organ.

KEY WORDS: resection of the liver; jejunum; muscular layer; remodeling. 